\title{
THE STUDY OF THEOLOGICAL "SIN" AND THE MEANING OF TRANSFORMATION BASED ON ROMANS 12:1-2
}

\author{
Tony andrean ${ }^{1)}$ David Ming ${ }^{2)}$ \\ 1) Charisma Theological College-Bandung \\ E-mail: ta.restiration@gmail.com \\ 2) Abdi Gusti Theological Seminary -Nganjuk \\ E-mail:david@sttabdigusti.ac.id
}

\begin{abstract}
"In the beginning He created the heavens and the earth, the earth was formless and empty; pitch darkness covered the great oceans, and the Spirit of God drifted over the surface of the earth '(Genesis 1: 1). chaotic "or" irregular. "(Warren Baker, Study OId Testament. AMG publisher, 1994: 2-3G.). Then in the process of creating humans for maintain the universe, but man falls into sin so that his mind or intellect is dominated by sin. What is produced by the mind ruled by sin? The Scriptures state the following: first, the human character is in vain (Romans 1:21). Second, it is not fair for anyone to be wise (Romans 3.11). Third, the human mind becomes evil (Ephesians 5: 4, the human mind is hostile to God and results in evil deeds 1.21) In further development, the universe is not getting better, it's actually getting more and more damaged. Natural disasters occur everywhere, economic conditions are chaotic, laws are violated by the leaders themselves, society is socially hostile to each other, crime is everywhere. With the chaotic event, humans crave a real change and share of activities carried out to realize these desires, among others, with the current plasticity, the transformation movement. The author conducted this research and the results are expected to provide information and additional insight for parties related to the problem of understanding the doctrine of existence and the meaning of sin, thus understanding the meaning of transformation based on the Bible to be changed to not sin anymore. The expected benefit is to provide correct knowledge to the congregation and God's servants regarding the effects of sin in their lives. Especially in service, how they anticipate sin and experience transformation changes in their lives. Thus it can remind every believer to remain faithful and abstain from every action that brings sin
\end{abstract}

Keywords: Sinfullness, Transformation, Roman 12:1-2

\section{INTRODUCTION}

In the New Testament, Rome was the center of Roman power. and also as the center of the world. About the founder of the city of Rome covered

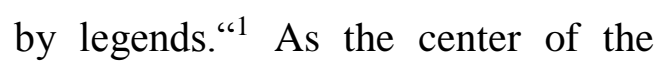
world, Rome was the home of many nations. The excavations prove that,

\footnotetext{
${ }^{1}$ Ola Tulluan, Introduksi Perjanjian Baru (IPB), (Jawa Timur: Yayasan Persekutuan Pekabaran Injil Indonesia [YPPII], 1999, ed. rev.). 122
} 
originally the city of Rome was a place wheremet and nationsmixed, not a place of just one ethnic group. This was influenced by the governmental system andsystem administrative of the Roman Empire which absorbed many cities, countries and nations. The city of Rome is called the "Eternal City". It is over flowing with luxury, history, andbuildings magnificent, as well as a fountain so that it is called the "Royal Sewers". ${ }^{2}$ Thecity which covers an area of 12 miles has a population of about one million people and half of them consist of slaves, because in this city the practice of buying and selling slaves was very widespread. The town contained about Jews 20,000but according to Witherington the number was between 40,000 or 50,000 . "3 This indicated that there were Jews quite a fewin the city. Evidenced by the existence of quite a lot of synagogues in the middle because usually the Romans, if they are rich, very rich and if they are poor, are very poor. " The Roman state covers all kinds of regions, climates, ethnic groups, languages, and cultures,

\footnotetext{
${ }^{2}$ Ludwig, Kota-kota dalam PB, hlm. 21

${ }^{3}$ Dietrich Kuhl, Sejarah Gereja Jilid I: Gereja Mula-mula di dalam Lingkungan Kebudayaan Yunani-Romawi (30-500), (Jawa Timur: Yayasan Persekutuan Pekabaran Injil Indonesia [YPPII],
}

not only united by Roman politics. but also by Greek culture As said by D. Kuhl, "In general knowledge, art, literature, and philosophy / logic of Greek culture (Hellenism) are the unifying tools. While in law, the fields of administration, and the military, Rome had an influential role. " ${ }^{4}$ In fact this implies that there were two powers which remained in existence, politically by Rome and culturally by Greece. The two of them successively ruled the world.culture Greek was so high that it was able to pervade the entirearea Mediterranean, even the capital city of theruler cross-between these two powers JI Packer states: The political power of Greece has passed, but the culture and atmosphere of Greece have become the foundation for the culture of the Roman empire, as the Roman writer, Horatius, observes that "The Greek captives had taken their captors captive. ." Greek art, literature, and governmental styles flourished throughout most of this Roman period. Even Greek koine remains the official language of business in the Near East, and the New

\footnotetext{
1998), 30

${ }^{4}$ Dave Hagelberg, Tafsiran Roma dari Bahasa Yunani, (Bandung: Kalam Hidup, 2004). 4
} 
Testament itself is written in this language. "5 This is a description of the city of Rome as Paul's letter address. Metropolitan cities, world centers, and plural in worldat that time, Rome. Concerning Rome has very littleclass nature. apostle Paul is referred to as the retroactive writer of Romans is found in Romans 1: 1. He is a servant of Jesus Christ, who is called to be an apostle and sanctified to preach the gospel of God. He was an Israelite, a descendant of Abraham, from the tribe of Banyamin (Rom. 11: 1; cf. Phil. 3: 5). According to Acts 22: 3 (cf. 21:39) Paul was born in the city of Tarsus in the land of Cilicia. So far the debate about who wrote Romans has not been a problem. Although theologians liberalhave argued that the apostle Paul did not write Romans. However debate has been resolved and almost all accept that the apostle Paul is the author of Romans. ${ }^{6}$ The evidence in this letter itself is very convincing. A number of events and figures written in this letter are also related in other books. For example,

${ }^{5}$ Charles Ludwig, Kota-kota pada Zaman Perjanjian Baru, (Bandung: Kalam Hidup, 1999).

${ }^{6}$ Jakob van Bruggen, Siapa yang Membuat Alkitab? Penyelesaian dan Kewibawaan Perjanjian Lama dan Perjanjian Baru, (Surabaya: Momentum
Paul's journey to Jerusalem to bring gifts from Macedonia (Rom. 15: 25-27 cf. Acts 19:21; 20:1-5; 21:15-19; 1 Cor. 16: 1-5; 2 Cor. . 8: 1-12; and 9:15), about Priscilla and Aquila (Rom. 16: 3 cp. Acts. 18: 2-3, 18-19), about longing for Paul to come to Rome (Rm. 1: 10-15; 15: 22-32 cf. Acts Ecclesiastica) alludes to this. There one finds a kind of list of New Testament writings grouped according to their characteristics, 19:21). External support regarding the existence of this letter is also very supportive emerging in the middle of the second century trying to establish a new church. Jacob van Bruggen stated, "The Marcion Church has its own teaching, its own liturgy, and most importantly, has its own canon." ${ }^{7}$ In its canon the Marcion church received all of Paul's letters except to Timothy and Titus. A work of another figure is Eusebius in his book History of the Christian Church (Hostoria above conclusion. Marcion (a heretic) ownPaul's Letters belong to thegroup homolougomene which is

2002). 49

${ }^{7}$ Christopher Wright, Hidup sebagai Umat Allah: Etika Perjanjian Lama, (Jakarta: BPK Gunung Mulia, 2007). 117 
recognized as canonical and there is no problem with their authorship. The data described above are strong evidence against what has been stated in Romans 1: 1, namely that the apostle Paul is the author of this letter, and at the same time states itsauthenticity unquestionable.

\section{RESEARCH METHOD}

This research method uses exegetical analysis of form text in the original Greek language which is analyzed by following the grammar and rules by looking at the Greek dictionary both in the form of text and style of language and grammar. from this analysis resulted in discussion and discussion of this journal.

\section{RESULTS AND DISCUSSION}

\section{Exegesis Romans 3:23}

For all have sinned and fall short of the glory of God. The meaning of losing the glory of God in the Greek language of doxa is the brilliance of the visible and visible beauty. OT, the meaning of the Shekinah glory is that God is in the midst of the Israelites, while in the NT it is evident in the life of the Lord Jesus as a human being, the Word or revelation of the Father John 1:14; 2 Corinthians 3:18; 4: 6 This means of losing the glory of God is losing man. ${ }^{8}$ The Greek word hysterein means to fall behind less valuable, to suffer a deficiency Matthew 19:20; 1 Corinthians 8: 8; II Corinthians 11: 5; Philippians 4:12. Deficiency in all people is an explanation of the meaning of sin.

That is true and everyone realizes that humans have fallen once from the brilliant light of God's perfection. The background of this Bible is hiding in the words of having sinned, losing the glory of Adam in his original state Genesis 1: 26-28 is Adam who was made in the image of God but He has lost his honor because Adam has commit a sin. With its absence. So everyone is a descendant of Adam has failed to achieve the purpose God intended. So if man has become acreation new he must have Christ in his person. So the image of God was returned to man. The view of Judaism Rabbi ate that Adam when He fell. Verses 24-25 But even if man is in a state of $\sin$, But the justification of

${ }^{8}$ Guthrie, New Testament Introduction, hlm. 407408, tahun yang diberikan oleh Donald Guthrie 57- 
God is free or by the grace of Christ is an atonement given by God and must be received by faith. The blood of Christ is the price accepted in the bounty of God, and because of this the sins of mankind are finally blotted out. The word redemption in Greek apoly-trosis means deliverance caused by the money or blood of the Lord Jesus Christ. The word atonement in Greek hilasterion comes from the verb hilaskomati which has three meanings to soften the heart, reconcile a person, have mercy or make atonement. In New Testament , use the second andmeanings third Luke 18:13, 1 John 2: 2. The meaning here does not mean that God the angryis made happy again by sinful human beings, but that the God Merciful pays the penalty for sin with the death of His Son who redeemed mankind from all debts of $\sin$. Although there is an idea of a just wrath for the sin that already exists in man, and this payment for the death of Jesus, because of his blood, is a symbol of the life sacrificed Genesis 9: 4; Leviticus 17:11; Deuteronomy $12: 23$ so the translation by his blood is accepted by Faith more accurately than in the blood of Christ. Because of the grace that God Himself has given
His Son freely. In other words, man is released, freewithout reward and only because oflove God'sfor man, by solving all and human sins, then the sins of the people of the past are not taken into account for a while, and the punishment for sin- sin is now also delayed; in all that is held for God to remain perfect. Davidson says that man wants to be master over hisdestiny own, seeking his own way from the way of God. "1 One thing that is certain and undeniable is the result is alienation. It is not only the relationship between God and man that is broken and as a fatal consequence is that human beings experience death both physically and spiritually.

Mankind has rebelled against God. This means that man no longer wants to submit to God's command. And therefore man severed his relationship with God. Man no longer has eternal life, and man no longer reflects the Divine life. This condition is what the Bible calls eternal death, or the seconddeath (Revelation 2:11; 20: 6-14;21: 8).

Gutrie said thatconsequence of the most commonsin the Apostle Paul mentioned was death. In I Corinthians 
$15: 26$, it is stated that death is considered the last enemy. In other words the very death is sin (I Corinthians 15:56). In Romans chapters 5 to 7 . Paul often links sin with death directly. Thepericope most obviousis Romans 5: 2-21, which initially asserts that death entered the world through sin and that sin ruled from the time of Adam to the time of Moses. ${ }^{9}$ The power of death continues to reach; the coming of Jesus Christ, who through His own death changed the situation and brought God's gift of salvation. Sin reigns in death, while grace reigns in righteousness (Romans 5:21). In Romans 7:13 it is revealed that sin brings death and transforms the whole body into a mortal body. Mortality which is the only end of $\sin$ (Romans 6:21) is completely contrary to the life given as a gift through Christ. Johns says that man has sinned and lost the glory of God (Romans 3:23) That means sin is already in all the world. This is known because in Romans chapter 5, Paul states that human beings know that all have sinned because death has spread that

\footnotetext{
${ }^{9}$ J. Verkuyl, Etika Kristen bagian Umum, (Jakarta: BPK Gunung Mulia, 1997). 117

${ }^{10}$ Christopher Wright, Hidup sebagai Umat Allah: Etika Perjanjian Lama, (Jakarta: BPK Gunung
}

human beings know that all have sinned because death has spread to all mankind. Adam and Eve disobeyed a special command of God, and therefore Adam and Eve died. The Bible explains that death is the result of sin. When a person sins, then as punishment is death (Ezekiel 18:20). In Romans 6:23, it is clearly said that death is the result of sin. Mankind has created many other ideas about sin and its consequences because man does not want to face the fact that the view of the Bible is true. In Genesis chapters 2 to 3 contain that death entered the world and every human being as a result of sin. Adam and Eve were created with the ability to live forever, but when Adam and Eve disobeyed God's command, Adam and Eve were sentenced to death, that is, death. ${ }^{10}$ when Adam held the authority of God, there was no sickness, no earthquake, no famine or poverty. Heaven ruled over the earth during Adam's lifetime in communion with God and in power through the authority and power delegated by God "11. But because of Adam's sin. the

Mulia, 2007). 167

${ }^{11}$ Willem A. VanGemeran, Penginterpretasian Kitab Para Nabi, (Surabaya: Momentum, 2007). 81 
destruction of everything under his authority has come. Because of his transgression, Adam has iven up his place in the spirit to God's enemy, the devil, this is what is called death which covers the physical andaspects spiritualas a whole. Physical death is the event of the separation of the soul from the body. In the Bible this event is considered part of the punishment for $\sin " 12$ That is the mostmeaning plausiblefor Genesis 2:17; 3:19; Numbers 16:29; 27: 3 . The prayer of Moses and the prayer of king Hezekiah. acknowledges the element of punishment in physical death (Psalm 90: 7-11 and Isaiah 38: 17-18). The same is true in the New Testament (John 8:44; Romans 4:24 and 25; 5: 12-17; 6: 9; 8: 3, 10 and 11; Galatians $3: 13 ; 1$ Peter 4: 6) . As a result of disobedience man will surely die (Genesis 2:17). What God means is the human body as well. God told Adam that the dust would return to the dust (Genesis 3:19). Paul says that all men will die in communion with Adam (I Corinthians 15:22), especially pointing to to physical death. In Romans 5:12, Paul lists the conception

\footnotetext{
${ }^{12}$ Henry C. Thiessen, Teologi Sistematika; Malang Gandum Mas, 1992 ) 273

${ }^{13}$ Henry C. Thiessen, Teologi Sistematika; Malang
}

of deathoverall. Physical, Spiritual and Immortal. Further, since the resurrection of the body is part of the redemption (Romans 8:23), we can conclude that physical death is the result of Adam's sin ${ }^{13}$ All those who deny the doctrine of original sinthought that the death of is the natural disadvantages, is based on the natural human physical condition, so that for man himself death is not proof that all human beings sin just as the death of an animal does not prove that all animals are sinful. The Bible teaches that physical death is part of the punishment for sin (Genesis 3:19; Job 5:18, 19; 14: 1-4; Romans 5:12; 6:23; 1 Corinthians $15: 21,22,56$; II Corinthians $5: 1,2,4 ; 1$ Timothy $1: 10$ ) The Bible explains that there is a direct link between disobedience to God and the consequences of death. James' letter describes the relationship that each person is tempted by his own desires, and if that desire has been fertilized and matured, it will give birth to death. Dobson, also said that all sins contain the characteristic of death. This is not means God just sits in heaven and is determined to

Gandum Mas, 1992 ) 182 
persecute human beings who sin. However, God forbids such behavior because God knows that sin will eventually destroy the perpetrator. It is not God who causes death, but sin. Sin is likened to cancer and consumes the person who cares for it. when God created man as a living being. Man is at peace with God who is the creator. Man was created in the image of God, to fulfill His purpose. God seals His nature,His attachesdivinity to man as long as man does not seek to escape from God. Satan enters between God and man, devising unworthy ideas The purpose of the devil is to make man declare his deliverance from God. And because man believes more in the devil, by disobeyingcommand God's, then since then man has been separated and separated from God. This fact shows that the relationship between man and God is broken, man no longer agrees with God. Hisno longer wish isGod's will. And as punishment is death. If man did not holy and even be strengthened in holiness; holiness will be strengthened into a holy character.

The Bible does not say anything about the body, but it seems that the

${ }^{14}$ Tom Jacobs, Paulus: Hidup, Karya, dan Teologinya, (Yogyakarta: Kanisius-Jakarta: BPK physical body (soul) will be transformed into a spiritual body similar to the bodies changed at the time Christ returns for the second time (compare Genesis 2: 7 with I Corinthians 15:44 -49) The only way to escape from $\sin$ is through Jesus Christ who has destroyed the power of death and brought about immortal life (II Timothy 1:10). John 14: 6 affirms that the only means of attaining eternal life is through Jesus alone. By his death Jesus reconciled man to God (Genesis 3:24; II Corinthians 5:18). By His resurrection, Christ destroyed the power of the devil, sin and eternal death (Genesis 3:15; Romans 6:10; compare Romans 5: 18-19; 1 Corinthians 15: 1228; 1 John 3: 8). The salvation that Jesus offers does not eliminatedeath physical, but it does provide assurance of eternal life with God "14 To better understand Romans $3: 23$, it is important to look at the context of this text in context. Here the author will explain the relationship of the sin in the past, surely man would remaitext with the verses before (Rom.), 3:23verses after the verses that are synonymous In 3: 1-, Paul speaks of the theological meaning of

Gunung Mulia, 1993), 95 
the unity of believers in Christ in His death and resurrection. "As sin has happened in history, so has the participation of believers in sin also happened in history. In other words, when Christ died on the cross, all who would be united with Him were also in him. "15. The starting point of Paul's description insection thisis from $3: 23$, as in Romans 5:20 "but the law is made perfect, so that there is no transgression; and where sin abounded, grace did much more abound ". This sentence can be misunderstood as an opportunity to live in $\sin$ (3: 8). To illustrate, Paul begins with a question: If so, what should we say? Can we persevere in $\sin$, so that the grace may increase? (6: 1). That is no longer possible because we have died to sin through the death of Christ. We are no longer ruled by sin and are not under the law but under grace (6:14). So the lawgiven isto state the condition of the sinner.

Through the law, sin has People who believe in Jesus Christ are no longer under the power of sin and the law, man has been moved.But the work of Christ does not just let go and

\footnotetext{
15 Joseph P. Free, Arkeologis dan Sejarah Alkitab, direvisi dan diperluas oleh Howard F. Vos, (Malang: Gandum Mas, 1997). 428
}

let it go without the 'operator'. In this case there is a transition from one slavery to another. ${ }^{16}$ After we were freed from the bondage of sin,now we areslaves of Christ.

Through this we see the love of Christ which is binding. Freedom from the law is not an opportunity to sin. Freed from the power of sin and the law will be effective when who has it comes to thegiven that freedom to the LordLord Jesus Christ, and to beservant His(Rom. 6: 15-23). Paul's statement in 6:14, "You do not live under the law but under grace", has a connection with 7: 1-6. Believers are dead to $\sin$ (Ps. 6), and now in chapter 7, Paul describes in what other ways believers are dead. The law requires the death and Christ repeats 6:14 by explaining further how to break the law. As stated by Th. Van den End, "In chapter 7 he gives an explanation of that freedom: freedom from the power of $\sin$ is freedom from the power of the Torah. Verse 5 focuses on the role of the Torah in our lives while still in sin. Life before death for the law and belonging to Christ is life in the spirit, Paul explains before we believe, our

\footnotetext{
${ }^{16}$ Ludji, Arti Taurat, . 60
} 
lusts are stimulated by the law so that we bear fruit for death. So, the law of the Torah has stimulated us and aroused lust, so that what it produces is the 'fruit of death'.

\section{The meaning of sin in the New Testament of the Greek}

First, "Hamartia". This word has the meaning of "not about the target or miss"17. This word is the Numbers and Ezekiel, destroying the wicked containing indications there is a loss, as well as something mornally wrong Genesis 3: 5; used 444 times, in Greek kakos poneros. Pointing to the act of rebellion against superiors, or un faith fulness to an agreement, or the rebellion of rebellion Job 34: 47,1 Kings 2:19, Isaiah 1: 2sin ancestral Isaiah 43:27 From the above understandings it can be concluded that: easily recognizing the form of his sin and then not committing sin (transgression, guilt) $\mathrm{Sin}$ in its essence in contrast to Sin has many forms, many terms are used. so that the Israelites get most commonly used word in theTestament New. This word

${ }^{17}$ K. Weiss, "X Dictionary of the New Testament, vol. IX, diedit oleh G. Kittel \& G. Friedrinch, (Grand Rapids, is written 174 times, and 71 times

among them are found in the letters of the apostle Paul. This word refers not only to the sinful deeds, but also to the stateheart of the eviland mind. Example usage: "For all have sinned, and come short of the glory of God" (Romans 3:23). Another example: "' She will give birth to a son and you will name Him Jesus, for He One is thewho will save His people from their sins (hamartia). " (Matthew 1:21). Second, "Parabasis".

This word comes from the verb "Parabaino" which means "violate". Conceptually it means walking across the line, as' disciples were Jesusaccused of "violating" the customs of their ancestors, and the phrase "step out" of Jesus' teaching in 2 John 1: 9. So, "parabasis" means "violation" or "deviate from what should be". In the New Testament, the word is always used in the case of definite violation of the law (Romans 4:15; 2 Peter 2:16).laws God'srequire man's obedience, and if manit means he is a disobeys"transgressor of the law" and sins so that the wrath of God

Michigan: Milliam B. Eerdmans Publishing Company, 1974), pp. 484-485 
will befall him (Romans 4:15).

Example usage: "After all, it is not Adam who is tempted, but the woman who is tempted and falls into sin (Parabasis)." (1 Timothy 2:14). Third, "Adikia".

This word has the meaning of "evil", "unrighteous deeds". This is an outward act or an unrighteous act just as the laws of the world say about the guilty. In court when all the hearings are over, the judge will convict, that the defendant is guilty. That is 5:17. Example usage: "All evil (adikia) is a sin, but there are sins that do not bring death." (1 John 5:17).

Fourth, "Anomia". This word comes from outside, which is considered to be something and the noun "Nomos" (law). Thus, anomia is "a condition without law because it ignores / disregards the law / disobeys the law". Example usage: "Every person who sins, also violates the law of God (anomia), because sin is a 'violation of the law of God' (anomia)." (1 John 3: 4).

Fifth, "Asebeia". This word has the meaning of wickedness and not knowing God (Titus 2:12). The sixth is "Paraptoma." This word has the meaning of error, not standing firm when it should be firm, not reaching what should be,transgression intentional (Matthew 6: 14-15, Romans 4:24; Galatians 6: 1; James 5:16). younger, meaning someone has done something wrong. This word is used in 1 John 1: 9; I John adjectives "Anomos" are negative particles The seventh is "Agnoema". It means not knowing, not understanding. Example of use: "but in thetent secondonly the High Priest enters once a year, and must with the blood he offers for himself and for the 'transgressions', made by his people 'unconscious' (agnoema). " (Hebrews 9: 7).

\section{THE ORIGIN OF SIN}

The Bible explains that sin originated with a free will, the devil. In the beginning the devil was aangel of God bright and glorious. He has rebelled and rebelled against God. The Bible explains that the devil's sin came from his pride. The first sin came from the will of the devil. God created the angels as His servants with free will, and it will be good as long as it is used properly and responsibly ( In the book of Isaiah 14: 12-17, explained by King James), the dawn son has fallen from heaven for disobeying God. Notice the word "I want" repeated five times, and 
finally "I want to equal the Most High!" (is 14). And compare it with II Thessalonians 2: 4, where the antichrist, the representative of the devil, will claim himself as "god". In the book of Ezekiel chapter 28 there is little evidence that the devil had fallen as a result of his pride (v. 17). Sin comes from Satan.

In Yesava chapter 14 it is explained that the devil rebelled and wanted to equate himself with God, and in the Book of Ezekiel it is explained that Satan fell into his sin and got rebellious against the Lord God and the Devil of God. The Bible explains that anyone who has sinned, not the Eastern Star / Lucifer (Bible version belonging to God (John 3: 8) explains that whoever continues to sin, He comes. from Satan because Satan sinned from the beginning. Satan could tempt Eve to break the same rules or prohibitions of God as Eve did in the beginning in the garden of Eden. "18 Brill, says that sin comes from a creature with free will: Satan was at first a great andangel, gloriousafter which Satan rebelled, hurt God.

\footnotetext{
${ }^{18}$ Donald Guthrie, Teologi Perjanjian Baru 2: Misi Kristus, Roh Kudus, Kehidupan Kristen, (Jakarta: BPK Gunung Mulia, 2006). 300

${ }^{19}$ Knox Chamblin, Paulus dan Diri: Ajaran Rasuli
}

God made the angels free will. "19 Sin entered the world, and Satan tempted man to sin. Satan always resisted the message of the gospel. God.The devil constantly tempts people to $\sin (1$ Corinthians $7: 5$ ) explains that man musteach other's guardintimate relations so that there will be no enmity (Acts 5:3), Satan is the most wicked and always hostile to the Children of God and of God's punishment.

The devil who first seeks to destroy human relationships by his creation. Man can be created by God (Genesis 1:26), saying that God creating man is not just a cover of all of God's creation. But in the creation of man himself contained the meaning of all the work of God. Humans are commanded to fill the earth. But because of sin so man became cut off from God became lost. As a result of sin, then punishment is given by God as a reward for the transgression that befell mankind, the devil and the world. The consequence of sin was that Adam and Eve had their consequences in this world.

bagi Keutuhan Pribadi, (Surabaya: Momentum, 2007). 140 
Eventually the earth could be cursed because human sin fell into sin Genesis 3: 17-18, Isaiah 55:13. Before Adam.falling into sin then man's relationship with God became broken, Adam had broken God's law, and his relationship with fellow man became chaotic 1 Samuel 15:23. Punishment which isconsequence a directas a sinner means that the punishment that befalls the person still gets his own punishment, body, soul and spirit. God cursed the Serpent. Then the Lord God said to the Serpent? Because thou didst it,cursed thou wastamong all the beasts of the field, and thy belly was cast, downand thou didst become dust in the dust of Genesis 3:14.

God said punishment to the suffering that Eve would receive. With all yourwhen you are pregnant I will do so much painswith the pains you will give birth to your child Genesis 3:16 Adam had to live a life of suffering through hard work. Because thou didst hearken to the words of thy wife, thou didst eat, and didst eat of the tree, of which I commanded thee not eat of it, and the that thou shouldstground was cursed, for thou didst seek thy sustenance from the land of thy life Genesis 3:17 In Genesis
3:17, God cursed the ground. Check out the thornsthistles andthat it will produce for you Genesis 3:18. The punishment for the world is that the world will go to ruin. In 2 Peter 3: 9 it is prophesied that at the end of the age the world will be burned with fire. One scholar, Leander S Keyser, commented, "According to the biblical interpretation in general, the first beings to be endowed with free will were angels. And thus, the origin of $\sin$ in this world is due to the creature who is free of his will is wrongly chosen. Indeed, sin must come from a creature who is free of his will, because otherwise, sin does not become a sin, only a mistake or fate.

Apparently some angels have begun to envy the power of God and do not fight the envy, then disobey God. That is the origin of the fall of some angels into sin. Sin changed them until they became demons and evil spirits. The leader is the devil, the most disobedient to God. "15 So, apparently sin has arisen in the Eastern Star / Lucifer when his will deviates from thepath wrong, which is to rebel against God. At the time some angels sinned, not all the angels sinned. This situation is not the same as Adam who 
brought sin upon all mankind.

\section{CONCLUSION}

Based on the context of understanding the meaning of the Transformation of sinless life in Romans 3:23 and Romans 12: 1-2 finally the author can give suggestions as follows:

1. So that people can understandunderstand the how to meaning of the word sin in (Romans 3:23) explains that because man has sinned so that man's relationship with God has been severed (separated from God).

2. 2. So that man can do what is right before God (Rom.12: 1-2). God wants man to always be aware of the sinful deeds that are already full before God, but even though man has sinned before God. If man truly came and repented ofsins his, the Lord Jesus has shed His blood to atone for all the forest of sins, and He has also blotted out, forgiven but $\mathrm{He}$ has also forgotten the sins that have passed.

\section{REFERENCES}

[1]. John Staumbaugh dan David Balch, Dunia Sosial Kekristenan Mula-mula, (Jakarta: BPK Gunung Mulia, 2004)

[2]. Charles Ludwig, Kota-kota pada Zaman Perjanjian Baru, (Bandung: Kalam Hidup, 1999)

[3]. Witherington III, Paul's Letter to the Romans: A Social Rehtorical Commentary, (Grand Rapids: Eerdmans Publidhing Company, 2004)

[4]. Ola Tulluan, Introduksi Perjanjian Baru (IPB), (Jawa Timur: Yayasan Persekutuan Pekabaran Injil Indonesia [YPPII], 1999, ed. rev.)

[5]. Dietrich Kuhl, Sejarah Gereja Jilid I: Gereja Mula-mula di dalam Lingkungan Kebudayaan Yunani-Romawi (30-500), (Jawa Timur: Yayasan Persekutuan Pekabaran Injil Indonesia [YPPII], 1998)

[6]. Dave Hagelberg, Tafsiran Roma dari Bahasa Yunani, (Bandung: Kalam Hidup, 2004)Jakob van Bruggen, Siapa yang Membuat Alkitab? Penyelesaian dan Kewibawaan Perjanjian Lama dan Perjanjian Baru, (Surabaya: Momentum 2002), hlm. 49 
Donald Guthrie menerima kesimpulan ini,

New Testament Introduction, (Leices-ter, U.K.: IVP, 1990)Th. van den End, Tafsiran Alkitab: Kitab Roma, (Jakarta: BPK Gunung Mulia, 2008)Keberadaan Petrus di Roma diduga pada akhir abad pertama $\mathrm{M}$, berdasarkan surat Clemens dari Roma kepada Ignatius dan bukti-bukti arkeologi di bawah Basilika St. Petrus di Vatican, Staumbaugh, hlm. 200

[7]. Merril C. Tenney, Survei Perjanjian Baru, (Malang: Gandum Mas, 2006) Willi Marxsen, Pengantar Perjanjian Baru: Pendekatan Kritis Terhadap Masalahmasalahnya, (Jakarta: BPK Gunung Mulia 2008)

[8]. John Drane, Memahami Perjanjian Baru: Pengantar Hostoris-Teologis, (Jakarta: BPK Gunung Mulia, 2008)

[9]. Dikutip oleh F.F. Bruce, Dokumendokumen Perjanjian Baru, (Jakarta: BPK Gunung Mulia, 2006)

[10]. Jakob van Bruggen, Paul Pioner for Israel's Messiah, (Phillipsburg: P\&R Publishing House, 2005

[11]. Robert E. van Voorst, Jesus Outside the New Testament: An Introductioan to the Ancient Evidence, (Grand
Rapids/Cambidge: William B. Eerdmans Pub Com., 2000)

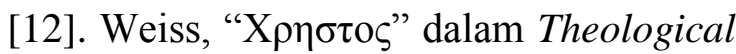
Dictionary of the New Testament, vol. IX, diedit oleh G. Kittel \& G. Friedrinch, (Grand Rapids, Michigan: Milliam B. Eerdmans Publishing Company, 1974)

[13]. van Voorst, Jesus Outside the New, p. 35. Juga beberapa tokoh-tokoh geraja mula-mula menyebutkan Chrestus kepada orang Kristen, seperti Justinus Martir (1 Apology4.1), Tertulianus, 197 (1 Apology 3.5), dan Laktantius, 309 (Devine Institutes 4.7.5), lht. Robert Voorst, Ibid., p. 36, lihat juga K. Weiss, TDNT, vol IX,

[14]. Tom Jacobs, Paulus: Hidup, Karya, dan Teologinya, (Yogyakarta: KanisiusJakarta: BPK Gunung Mulia, 1993)

[15]. Joseph P. Free, Arkeologis dan Sejarah Alkitab, direvisi dan diperluas oleh Howard F. Vos, (Malang: Gandum Mas, 1997)

[16]. Guthrie, New Testament Introduction, hlm. 407-408, tahun yang diberikan oleh Donald Guthrie adalah 57-59

[17]. Douglas J. Moo, The Epistle of the Romans (NICNT), edited by Gordon D. Fee, 
(Grand Rapinds: Eerdmans, 1996)

[18]. Donald Guthrie, Teologi Perjanjian Baru 2: Misi Kristus, Roh Kudus, Kehidupan Kristen, (Jakarta: BPK Gunung Mulia, 2006)

[19]. J. Knox Chamblin, Paulus dan Diri: Ajaran Rasuli bagi Keutuhan Pribadi, (Surabaya: Momentum, 2007)

[20]. Glenn W. Baker, The New Testament Speaks, (New York: Harper \& Row Publishers, 1969)

[21]. Thomas R. Schreiner, Romans (BECNT), Grand Rapids: Bacer Academic,1998)

[22]. Herman Ridderbos, Paulus: Pemikiran Utama Teologinya, (Surabaya: Momentum, 2008)

[23]. J. J. W. Gunning, Tafsirab Alkitab: Kitab Galatia, (Jakarta: BPK Gunung Mulia, 2001

[24]. Gordon D. Fee, Paulus, Roh Kudus, dan Umat Allah, (Malang: Gandum Mas, 2004

[25]. William Dyrnees, Tema-tema dalam Teologi Perjanjian Lama, (Malang:
Gandum Mas, t. th.

[26]. Indriani Bone, Paul Hidayat, dan Anwar Tjen (ed.), Berteologi dalam Anugerah, (Cipanas: STT Cipanas, 1997

[27]. Christopher Wright, Hidup sebagai Umat Allah: Etika Perjanjian Lama, (Jakarta: BPK Gunung Mulia, 2007

[28]. Willem A. VanGemeran, Penginterpretasian Kitab Para Nabi, (Surabaya: Momentum, 2007

[29]. Richard L. Pratt, Ia Berikan Kita Kisahnya: Panduan bagi Siswa Alkitab untuk Menafsirkan Narasi Perjanjian Lama, (Surabaya: Momentum, 2005

[30]. David L. Baker, Mari Mengenal Perjanjian Lama, (Jakarta: BPK Gunung Mulia, 2005

[31]. Wright, Hidup sebagai Umat Allah, 1996 J. Verkuyl Kristen bagian, Etika Umum, (Jakarta: BPK Gunung Mulia, 1997)

[32]. Billy Kristanto, Ajarlah Kami Bergumul: Refleksi atas Kitab Mazmur, (Surabaya: Momentum, 2008

[33]. Ludji, Arti Taurat, 2000Lukas Tjandra, Latar Belakang Perjanjian Baru, 
Journal Kerugma

E-ISSN: 2622-1039

P-ISSN: 2621-8038

jld. II (Agama), (Malang: Literatur SAAT, 2008)Dalam jilid II, Lukas Djandra memuat peraturan agama Yahudi di bagian apindeks yaitu hal-hal yang harus dilakukan atau dilarang (356 butir), R. S. Russell, Penyingkapan Ilahi, Pengantar ke dalam Apokaliptik Yahudi, (Jakarta BPK Gunung Mulia, 2007)

[34]. Linwood Urban, Sejarah Ringkas Pemikiran Kristen, (Jakarta: BPK Gunung Mulia, 1996)

[35]. Jagersma, Dari Aleksander Agung sampai Bar Kokhba (Sejarah israel dari \pm 330 SM-335 M), (Jakarta: BPK Gunung Mulia, 2003

[36]. Charles S. Mackenzie, "Humanisme Yunani Klasik" dalam Membangun Wawasan Dunia Kristen. Volume 1: Allah, Manusia, dan Pengetahuan (W. A. Hoffecker, ed.). (Surabaya: Momentum, 2006)

[37]. Anthony A. Hoekema, Alkitab dan Akhir Zaman (The Bible and the Future), (Surabaya: Momentum, 2004),B. F. Drewes, wilfrid Haubeck, Heinricvon Siebenthal, Kunci Bahasa Yunani Perjanjian Baru.(Jakarta BPK Gunung Mulia, 2006).
[38]. C.E.B. Cranfleld, A Critical and Exegetical Commentary on The Epistle to The Romans( Edinburgh: T\&T Clarck Limited, 1975).

[39]. Elwell, Comfort, Wesley: Tyndale Bible Dictionary (Wheaton, 11l. Tyndale House Publishers, 2001).

[40]. Harold K. Moulton, The Analytical Greek Lexicon Revised.(Grand Rapid,Michigan: Zondervan Publishing House, 1992).

[41]. Iman santoso, Transformasi Indonesia(Jakarta: Metanonia, 1996).

[42]. James Strong, The Exhaustive Concordance of the Bible (Ontario: Woodside Bible Fellowship, 1996)

[43]. (Electronic Book).Marvin Richardson Vincent, WordStudies in the New Testament (Bellingham, WA: Logos Research Systems, lnc., 2002)

[44]. (Electronic Book). Warren Baker, The Complete World Study Old Testament. (AMG Publishet 1994) 